ISLLAC

Journal of Intensive Studies on Language, Literature, Art, and Culture

Vol. 1 No. 1 September 2017

\title{
FEEDBACK AND SELF REGULATION IN WRITING LEARNING ASSESMENT IN JUNIOR HIGH SCHOOL
}

\author{
Titik Harsiati \\ State University of Malang \\ titik.harsiati.fs@um.ac.id
}

\begin{abstract}
This article aims to analyze the pattern of feedback and self-regulation in writing assessment in junior high school. The feedback in the writing assessment in junior high school is done quantitatively in the form of a score in the final product. Self-regulation in the assessment as a learning tool is done in the form of reflections on competencies that have been mastered and have not been mastered. The implementation of feedback and self-regulation in the learning assessment in junior high school is not suitable yet in terms of reversal principle and self-regulation in the context of assessment as a learning tool.
\end{abstract}

Keywords: feedback, self-regulation, writing learning assessment, junior high school

\section{INTRODUCTION}

Assessment and learning are two interrelated things (Brown, 2005). Assessment has an important role to create the $21^{\text {st }}$ century generation. The $21^{\text {st }}$ century generation is expected to own special skills as to adapt to the digital era. According to the International Society for Technology in Education (2007) there are six $21^{\text {st }}$ century skills, namely (a) creativity and innovation, (b) communication and collaboration, (c) smoothness of research and information, (d) critical thinking, problem-solving, and decision-making, (e) digital citizenship, and ( $\mathrm{f}$ ) technology concepts and operations. The range and form of the preexisting information changes due to the occurrence of digital skills, but one thing that will not change is the skill itself. In order to prepare the 21st century generation, it is necessary to revitalize the assessment strategy. The assessment required is an assessment that can provide constructive feedback and serves as a learning tool. The assessment of such characteristics is necessary to prepare students to be lifelong learners and to be 
ISLLAC

Journal of Intensive Studies on Language, Literature, Art, and Culture

Vol. 1 No. 1 September 2017

reflective. This explanation aims to (1) describe the pattern of feedback in the writing assessments in junior high school (2) describe the use of self-regulation in writing assessments, (3) analyze feedback according to the principles of feedback, and (4) analyze self-regulation in the assessment perspective as learning tools (assessment as learning).

\section{The nature of the Assessment for Learning and Assessment as Learning}

Assessment in learning is categorized into three types; they are an assessment for learning, assessment as a learning tool, and assessment after completion of learning. Assessment as a learning tool is an assessment to guide and provide opportunities for students to monitor and reflect critically on their learning processes and outcomes. Assessment as a learning tool also helps students identify the steps they need to take next to improves their learning quality. Assessment as a mean of learning explores what students think about their learning processes and outcomes, the learning strategies that are used, things that support or hamper their learning, and how they make adjustments and improve their learning quality. Assessment as a learning tool is related to the reflection of activities, accurate and consistent monitoring and adjustment activities by students. This assessment requires the involvement of students in considering and questioning their own thinking. Assessment as learning is simply the process of students recording their own learning processes and the outcomes of it.

The function of assessment as a learning tool is to provide a descriptive and accurate feedback for each student so that it will help develop independent learning habits. In addition, the assessment works to encourage students to focus on the learning process they are undergoing (not on the ability to answer correctly). Students are given the opportunity to reflect on ideas to adjust, rethink, and articulate their learning processes and results. 
ISLLAC

Journal of Intensive Studies on Language, Literature, Art, and Culture

Vol. 1 No. 1 September 2017

\section{Feedback Patterns in the Writing Assessment in Junior High School}

Assessment for learning is the use of information from the learning process descriptions of the adjustment of learning and the adjustment of the student learning strategies. Assessment, learning, and learning process are related and give each other information for adjustment. Feedback plays an important role in the assessment as a means of writing learning. Research on writing learning assessment in junior high schools in Malang showed the following results.

Based on the results of the research above, it is concluded that the writing task is done with the theme stimulus and done in the class or assigned outside of the classroom. The reverse of the class writing process is done in a general classical fashion. The feedback to the final product is in the form of a score with a compliment (good) for the work with a high score. The assessed aspect has not yet integrated, the aspect that was assessed focused on Value was done in the form of a score using an analytical rubric. Character values have not been integrated with scanning either. Integration of character values found in the determination of the writing theme.

\section{The Effectiveness of Feedback in The Context of Assessment as Learning}

Feedback is information provided by the teacher to the student about certain behaviors in order to improve students' performance. In the writing assessment, feedback provides students with a description of the writing process and the students' writing. Feedback includes both strength and deprivation. According to Black (2004), feedback can be a verbal feedback about error patterns, feedback through written comments, and through video or audio recording. It is further explained that the inverse is categorized in two, ie negative and positive feedback. Negative feedback is given to students whose performance is still not as expected by the teacher. In this negative feedback, teachers provide information that the students' performance is not good enough with examples of how they should be performing. The purpose of giving negative feedback is corrective so that students can improve their performance. Here's some example of effective negative reply. 
ISLLAC

Journal of Intensive Studies on Language, Literature, Art, and Culture

Vol. 1 No. 1 September 2017

"Dewi, pantun yang kamu buat masib belum tepat. Amati bunyi akbir larik pertama dan ketiga. Apanya yang kurang tepat? (Dewi tetap belum bisa menemukan kesalahannya). Seharusnya bunyi akbir larik pertama sama dengan bunyi akbir larik ketiga.

Pantun yang dibuat kelompok 3 bermasalah pada jumlah suku kata. Jumlah suku katanya terlalu banyak. Berari perlu diapakan? (siswa menjawab: dilakukan pengurangan suku kata supaya imbang dengan larik lainnya). Iya perlu dilakukan pengurangan. Kamu perlu melakukan pengurangan kata tetapi dengan makna yang bampir sama.

Cerita yang kamu buat kurang bagus karena tidak ada konfliknya. Perlu diubah watak tokohnya dan ditambah kejadian luar biasa sehingga konflik terjadi baik antartokoh, pada diri tokoh sendiri

Pengembangan konflik dalam cerita yang kamu tulis kurang tajam. Bagaimana jika didatangkan tokoh baru atau diberikan kejadian luar biasa pada tokoh sehingga konflik cerita semakin bagus.

Positive feedback is given to the students in hopes that the student will maintain its performance in the future. Positive feedback should be coupled with awards (rewards) or strengthening in the form of praise or applause, or any other form. On the positive feedback, teachers provide information about the performance of students who are good for reasons that are considered good elements. Below are some examples of effective positive feedback.

"Bagus Andi, cerita yang kamu tulis benar-benar orisinal. Konflik yang dibangun tajam dan merangsang rasa ingintabu pembaca. Babasa yang digunakan juga sangat segar.

Without being given feedback, students will not be able to learn to write effectively by just writing; they will not be able to read well by just reading. Without feedback, it means that students do not know how the learning outcomes (whether appropriate or good and where the shortcomings). Without feedback, students find it difficult to improve their understanding or performance.

Some principles that must be considered by the teacher in giving feedback are (1) give back as soon as possible; (2) provide specific feedback; (3) emphasize the behavior or thing to be corrected, not others; (4) provide feedback according to the child's developmental level and condition; (5) reward together with positive feedback on good performance; (6) when giving negative feedback, as well as 
ISLLAC

Journal of Intensive Studies on Language, Literature, Art, and Culture

Vol. 1 No. 1 September 2017

show/illustrate how the right thing/performance is right; (7) help students focus on the process, not on results; (8) teach students how to get feedback from themselves and how to judge its own performance.

In relation to the principle of reversal in the context of the writing assessment, it can be concluded that the results of the reverse research in the junior high school have not been appropriate. Feedback is a common score on a writing assignment. Feedback in class is commonly given in writing completion. The feedback to the writing skills on out-of-class writing assignments are in the form of scores of writing products.

Effective feedback should answer three questions. First, the feedback to the process related to the intended direction whether it is suitable with the competence to be achieved. The second question is how to achieve the goal and whether it is in accordance with the right process. The next question is related to the progress/ability in achieving competence.

According to Haati (2007) feedback is classified into four levels: feedback about the task, feedback about the processing of the task, feedback about selfregulation, and personal feedback about the self as a person). First, feedback that focuses on the task or product. This feedback is guided by questions such as whether the task I am working on is right or wrong. The feedback is related to the assignment or product the student is working on whether the job is correct or incorrect. This level of feedback may include directions to get more. Second, feedback can be directed to the process used to create a product or complete a task. This kind of feedback is more directly aimed at information processing. Third, feedback to students can be focused on the level of self-regulation, including greater skills in self-evaluation or self-confidence. Fourth, feedback can be personal in the sense that it is directed at "self" in specific situations according to the characteristics of the students 'questions are related to the follow-up that will be done so that the achievement of competence will be even better.

At this level, students are invited to question whether students already know the main features of opening an argument. The learning behavior has a major effect 
ISLLAC

Journal of Intensive Studies on Language, Literature, Art, and Culture

Vol. 1 No. 1 September 2017

on self-efficacy and self-regulatory. Thus, students are encouraged better and more easily do the task. Fourth, feedback can be personal in the sense that it is directed at "self" in specific situations according to the characteristics of the students "questions are related to the follow-up that will be done so that the achievement of competence will be even better.

Self-regulation is an important aspect of the assessment activity. In particular, self-regulation is related to students' ability to reflect on their own critical learning activities in order to determine the next learning step. Self-regulation is closely related to the assessment characteristics as a means of learning (assessment as learning). The assessment has several characteristics, namely (a) integrating with the daily learning process, (b) carried out continuously during the implementation and after the learning takes place, (c) the students learn to think critically of their learning activities and learn their friends, (d) the teachers get information about the process and the learning outcomes of the students from the perspective of the students themselves, (e) the students identify the weaknesses and the advantages of learning, ( $\mathrm{f}$ ) the students determine the learning strategy according to their learning style, (g) the students reflect on their own learning (self-assessment), (h) the teacher gives students the opportunity to express their own learning difficulties, (i) the students learn to provide peer assessment, (j) the students learn from their peer's critical assessment (peer assessment), (k) students provide feedback and assessment to their friends according to the capacity they have with the peer assessment, and (l) assessment as the learning activities as peer and self-assessment at the secondary school level become part of formative assessment for improvement of learning process (Black,).

Self-regulation relates to facilitating students to be able to review their skills, knowledge, and cognitive strategies. Self-regulation evaluates comprehension, a strategy used in writing task work, improvement of goal achievement. Selfregulation is closely linked to the growth of commitment value, self-control, and self-confidence. It is a way that students use to monitor the process and learning outcomes. Implementation of self-regulation fosters self-control, self-control, self- 
ISLLAC

Journal of Intensive Studies on Language, Literature, Art, and Culture

Vol. 1 No. 1 September 2017

direction, and self-discipline. Thus, self-regulation includes thoughts, feelings, and behaviors. Assessment as a learning tool developed with the assumption that students have different learning needs and able to reflect the activities and learning outcomes. In order to make the learning suitable with the needs of students, the teacher provides opportunities for students to assess their own learning processes and results. To that end, teachers need to design techniques and instruments that facilitate students to conduct self-assessment.

In the assessment as a means of learning (assessment as learning), the teacher provides an opportunity for students to reflect on the activities and learning outcomes. In addition, students learn to provide constructive assessments and feedback on the processes and work of their friends. It is based on the belief that students are seen as subjects able to assess themselves and each other (peers). Assessment as a learning tool is necessary based on the following things.

- Students need to understand how to learn with the right strategy.

- Students have different perspectives (perspectives) from the teacher's perspective

- Some students prefer to learn from their friends

- Students need to be involved in reflecting on their learning and providing feedback to their friends

Assessments for learning have a guiding function and provide an opportunity for each student to monitor and reflect on their own critical learning activities and determine the next step or learning strategy. According to Susan (2008), the metacognitive formation can be done by giving students the opportunity to critically reflect the steps and learning strategies. By having good metacognitive abilities, students get descriptive and accurate feedback that can help or develop self-learning habits

The benefits of self-regulation in the writing assessment include (a) directing students to focus on the task and learning (rather than providing the correct answer), (b) giving students ideas for assessing, rethinking, and demonstrating their learning activities, (c) encouraging students to think (d) encourage students to learn from each other (from peers), (e) creating conditions so that teachers and students 
ISLLAC

Journal of Intensive Studies on Language, Literature, Art, and Culture

Vol. 1 No. 1 September 2017

can discuss alternative solutions, and ( $\mathrm{f}$ ) encouraging students to learn from each other (from peers) teachers get reports of learning activities in the perspective of students.

In implementing the assessment as a means of learning teachers need to design an instrument that can provide data related to the learning steps undertaken by students, things that have been understood by students, things that students have not understood, the feelings of students in achieving goals, the process of the most preferred, which students must do to improve their learning. Assessment activities as a means of learning are conducted in the following ways.

In particular, self-regulation is closely related to the metacognitive abilities consisting of the following activities.

1) Goal setting: to organize to know what to expect when reading or learning.

2) Planning: organize them in using the time and resources they have to do the learning task.

3) Controlling attention

4) Organizing in order to focus on the subject matter and clear the mind of the things that have the potential

5) Disturbing concentration and emotion. Application of learning strategies

6) Organize in order to choose a learning strategy that fits the specific objectives to be achieved.

7) A self-motivated strategy of self-regulation in order to maintain motivation with various strategies, such as finding ways to make a tedious activity more interesting and challenging, or imagining yourself succeeding in completing a burden or a difficult task.

8) Request for help

9) Sometimes the self is unable to do everything without help. There are tasks that are done independently and sometimes there are tasks that need the help of others. Students will specifically seek help from someone who can help to become more independent in the future or the future. 
ISLLAC

Journal of Intensive Studies on Language, Literature, Art, and Culture

Vol. 1 No. 1 September 2017

10) Self-regulation to self-regulate in order to always monitor progress or development toward the goal to be achieved, and sometimes change the learning strategy or modify the goal if necessary.

Schunk and Zimmerman (2004) explained that metacognition is the ability of individuals to plan, organize or organize, instruct themselves, monitor, and evaluate in learning activities. In addition, self-regulation is also related to motivation. Zimmerman and Schunk said that motivation is a driver (drive) that exists in the individual self that includes perceptions of self-efficacy, autonomy competencies possessed in learning activities. Motivation is a function of the basic need to control and relate to the sense of competence that each individual has. Behavior is an individual effort to organize, select, and utilize the environment and create an environment that supports learning activities.

The factors that affect the self-regulation include external and internal factors. External factors affect self-regulation in at least two ways. First, they provide a standard for evaluating our behavior. Environmental factors interact with personal influences, forming individual standards for evaluation. For example, through observation of others, we form standards to evaluate self-performance. From these examples, personal factors influence what standards we will learn, but the drive from the environment also has a role to play. Second, external factors affect self-regulation by providing a way to gain reinforcement. Intrinsic rewards are not always enough, we also need incentives from external factors. For example, a writer needs more reinforcement than self-satisfaction in order to accomplish a writing Support from the environment in a material form or praise and support from others is also necessary. Thus, external factors affect self-regulation in two ways: standard and reinforcement.

There are three internal needs in the process of self-regulation, namely selfobservation, assessment process, and self-reactions. Self-Observation is done based on the quality factor of appearance, the quantity of appearance, the originality of selfbehavior, and so on. Self-observation of the performance has been done. Humans are able to monitor his performance even if it is incomplete or accurate. We 
ISLLAC

Journal of Intensive Studies on Language, Literature, Art, and Culture

Vol. 1 No. 1 September 2017

selectively choose a number of aspects of behavior and ignore other aspects that are maintained usually in accordance with self-concept. The Assessment Process depends on four things: personal standards, reference performance, activity values, and performance improvements. Most activities should be assessed by comparing with external measures, may be standard norms of social comparison, comparison with others, or collective comparisons. Of most activities, we evaluate performance by comparing it to reference standards. Humans respond positively or negatively to their behavior depending on how these behaviors are measured and what are their personal standards. Bandura believes that humans use a reactive and proactive strategy to regulate themselves. That is, humans attempt to reactively reduce the conflict between achievement and purpose, and after successfully eliminating it, they proactively set new goals higher. Self-reinforcement depends not only on the fact that it can directly follow a response: in fact, largely depends on the use of our cognitive ability to mediate the consequences of behavior. Humans prepare a standard for performance, which, when fulfilled, tend to regulate behavior with selfgenerated rewards, such as pride and self-satisfaction. When humans fail to meet these standards, their behavior will then be followed by self-dissatisfaction or selfcriticism.

The findings of this study show the success of students with the role of many self-regulations in learning to support the results of previous research in line with the results of this study. Heaatie (2007) found that students with self-regulation in learning are higher than students who do not perform other social roles. Mezei's research (in Haatie: 2007) also reveals that a learner in adulthood despite having worked still does self-regulation in learning to aid in their understanding. Motivation to master the material, the absence of forced feelings in learning as well as a relevant subject matter for application in work life make self-regulation in learning can be done. 
ISLLAC

Journal of Intensive Studies on Language, Literature, Art, and Culture

Vol. 1 No. 1 September 2017

\section{The Effectiveness of Self-Regulation in the Writing Learning Assessment}

The results of the study found that self-regulation in writing assessment is done by reflection of competencies that have been mastered have not been mastered. The main thing developed in the assessment activities as a means of learning is the growth of self-regulation ability or metacognitive ability in students. Self-regulation and metacognitive are the key skills needed in the 21st century (Susan, 2008).

Self-regulation is closely related to metacognitive. Susan (2008) explains that metacognitive is the ability to control the domain or cognitive aspect. Metacognitive is basically a person's ability to learn, which includes how best to learn to do, what is and is not yet known, what strategy will be done to improve learning. Metacognitive consists of three stages: planning on what should be learned, to where the attainment of how to learn, when to learn, what steps are being taken to study, and monitoring of the learning process being done. Metacognitive is a high-level thinking activity. The metacognitive ability allows students to control the thinking process that is going on for them.

Metacognitive includes two components, metacognitive knowledge, metacognitive experience or regulation. In other words, it can be concluded that there are two important components to metacognitive, that is (a) what we know and what we do not know, and (b) the regulation of how we learn. The two metacognitive components, metacognitive knowledge and metacognitive regulation, each have sub-components. Metacognitive knowledge consists of declarative knowledge, procedural knowledge, and conditional knowledge. Metacognitive regulation consists of sub-capabilities, planning strategies, information management strategies, monitoring comprehension, effectiveness strategies, and evaluation.

The first component of metacognitive knowledge is the knowledge of oneself as the learner, the strategy used, the skills, and the learning resources he needs for learning. The second component of metacognitive knowledge is the knowledge of how to use what is already known in the declarative knowledge in its learning activities. The third component is the knowledge of when to use a procedure, skill, or 
ISLLAC

Journal of Intensive Studies on Language, Literature, Art, and Culture

Vol. 1 No. 1 September 2017

strategy and when such things are not used, why a procedure proceeds and under what conditions it takes, and why a procedure is better than other procedures.

Cognitive regulation consists of three sub-components. The first is planning component that demands students' ability in planning their learning activities. Second, the strategy to manage information, namely the ability to manage information related to the learning process undertaken. The third is the ability to monitor the learning process and matters relating to the process. Fourth is the ability to debug strategies is a strategy used to correct wrong actions in learning. And fifth is the ability to evaluate the effectiveness of their learning strategy, whether they will change their strategy, give up on the situation or end the activity.

As stated in the previous description that metacognitive is essentially the ability to learn how learning should be done in which the activities are considered and carried out (1) developing a learning activity plan, (2) identifying its advantages and disadvantages with regard to learning activities, (3) a learning program for new concepts, skills and ideas, (4) identifying and using their daily experiences as a source of learning, (5) utilizing modern technology as a source of learning, (6) leading and participating in discussions and solutions (7) learning from and benefiting from the experiences of certain people who have succeeded in a particular field, (8) learning from and taking advantage of the experiences of certain people who have succeeded in a particular field, (9) understanding the factors supporters of learning success. Based on the exposure it appears that one's success in learning is influenced by his metacognitive ability. If each learning activity is conducted with reference to the indicators of learning how to learn as mentioned above, optimal results will undoubtedly be achieved easily

Based on the explanation above, it can be concluded that effective selfregulation in writing assessment should include product reflection, personal / feeling response, and follow-up. The implementation of a writing assessment needs to be developed by self-regulation focused on reflecting on the writing process, feelings, strategies used, and follow-up to improve learning. So, the feedback of the research 
ISLLAC

Journal of Intensive Studies on Language, Literature, Art, and Culture

Vol. 1 No. 1 September 2017

in learning writing in the junior secondary is less relevant from the perspective of assessment as learning.

\section{CONCLUSION}

Assessments for learning and assessment as a learning process are still poorly implemented in junior high school writing. The reply is done in the form of writing a final assignment. The assessment is an assessment of learning based on measurable measurements at the end of the lesson. Effective feedback is a form of teacher assistants in the process of achieving student writing results to the fullest. Implementation of assessment is a means of learning (assessment as learning) in the form of self-assessment of competencies that have been mastered and who have not been mastered. From the view of the principle of repayment, feedback on the assessment of writing is not in accordance with the principle of countermeasures. The feedback should be based on products, processes, self-regulation, or personal, need to focus on and focus on processes and outcomes.

Self-regulation is an important thing in the writing assessment in junior high school is done by reflection of competencies that have been mastered and who have not mastered. Judging from the principle of self-regulation in the assessment, the implementation of a writing assessment needs to be developed by self-regulation focused on reflection on the writing process, feelings, strategies used, and follow-up to improve learning.

\section{REFFERENCES}

Black, P, Harrison, C, Lee, C, Marshall, B \& Wiliam, D. (2003). Assessment for Learning - Putting it into practice, England: OUP, Berkshire.

Brown. (2004). Language Assessment. London: Pearson Inc

Stevenson, N. (2006). Young Person's Character Education Handbook. JIST Publishing, Inc.

Susan, E. 2008. Metacognition in Literacy Learning. Theory, Assessment, Instruction, and Professional Development New Jersey: Lawrence Erlbaum Associates, Inc. 
ISLLAC

Journal of Intensive Studies on Language, Literature, Art, and Culture

Vol. 1 No. 1 September 2017

Harsiati, T. (2011). Implementasi E. V "Motivational and Self Regulated Learning Components of Classroom Academics Performance. Journal of Educational Psychology, Vol Asesmen in Pembelajaran Bahasa Indonesia di SMP. Hibah Bersaing

Earl, L.M. (2003), Assessment as learning: Using classroom assessment to maximise student learning. California: Corwin Press.

Pintrich, P. R. , \& De Groot,. 82, no. 1, 33 40,1990).p.33

Cheng, E. C. (2011). The role of Self-regulated learning in enhancing learning performance. The International Journal of Research and Review, 61), 1-

Hattie, J. \& Helen, T. (2007).The Power of Feedback. In Review of Educational Research March 2007, Vol. 77, No. 1, pp. 81-112 DOI: 10.3102/003465430298487.

Zimmerman , B. J. \& Schunk, D.H. (2004). Self Regulating Intellectual Processes and Outcomes: NJ : Erlbaum Associate Publishers 
ISLLAC

Journal of Intensive Studies on Language, Literature, Art, and Culture

Vol. 1 No. 1 September 2017

\section{Appendix A Table 1: Teachers' Feedback to Students' Writings}

\begin{tabular}{|c|c|c|c|}
\hline Learning Goal & Task & Criteria & Feedback \\
\hline $\begin{array}{l}\text { Menciptakan } \\
\text { teks deskripsi }\end{array}$ & $\begin{array}{lr}\text { Membuat } & \text { teks } \\
\text { deskripsi lingkungan } \\
\text { sekitar }\end{array}$ & $\begin{array}{l}\text { Kelengkapan struktur } \\
\text { Penggunaan kalimat } \\
\text { Penggunaan kata } \\
\text { Penggunaan ejaan }\end{array}$ & $\begin{array}{l}\text { Berupa skor pada } \\
\text { produk akhir }\end{array}$ \\
\hline $\begin{array}{l}\text { Menciptakan } \\
\text { teks cerita } \\
\text { fantasi }\end{array}$ & $\begin{array}{l}\text { Tugas membuat } \\
\text { cerita fantasi dengan } \\
\text { tema yang ditentukan } \\
\text { (dilakukan di luar jam } \\
\text { pelajaran) }\end{array}$ & $\begin{array}{l}\text { Kelengkapan struktur } \\
\text { Penggunaan kalimat } \\
\text { Penggunaan kata } \\
\text { Penggunaan ejaan }\end{array}$ & $\begin{array}{l}\text { Diberikan skor } \\
\text { dan pujian pada } \\
\text { produk hasil akhir }\end{array}$ \\
\hline $\begin{array}{l}\text { Menulis } \\
\text { pantun }\end{array}$ & $\begin{array}{l}\text { Tugas membuat } \\
\text { pantun dengan tema } \\
\text { tettentu (dikerjakan di } \\
\text { dalam kelas) }\end{array}$ & $\begin{array}{l}\text { Ketepatan syarat larik } \\
\text { pantun } \\
\text { Ketepatan rima } \\
\text { pantun Penggunaan } \\
\text { kata } \\
\text { Kelogisan }\end{array}$ & $\begin{array}{l}\text { Balikan umum } \\
\text { secara klasikal dan } \\
\text { diberi skor pada } \\
\text { hasil akhir }\end{array}$ \\
\hline $\begin{array}{l}\text { Menulis teks } \\
\text { prosedur }\end{array}$ & $\begin{array}{l}\text { Tugas membuat teks } \\
\text { prosedur (dikerjakan } \\
\text { di dalam kelas) }\end{array}$ & $\begin{array}{l}\text { Kelengkapan struktur } \\
\text { Penggunaan kalimat } \\
\text { Penggunaan kata } \\
\text { Penggunaan ejaan }\end{array}$ & $\begin{array}{l}\text { Balikan umum } \\
\text { secara klasikal dan } \\
\text { diberi skor pada } \\
\text { hasil akhir } \\
\text { diberi skor secara } \\
\text { individu }\end{array}$ \\
\hline $\begin{array}{l}\text { Menulis hasil } \\
\text { observasi }\end{array}$ & $\begin{array}{lr}\text { Tugas menulis } \\
\text { rangkuman teks hasil } \\
\text { observasi (tugas di } \\
\text { luar kelas) }\end{array}$ & $\begin{array}{l}\text { Kelengkapan struktur } \\
\text { Penggunaan kalimat } \\
\text { Penggunaan kata } \\
\text { Penggunaan ejaan }\end{array}$ & $\begin{array}{l}\text { Balikan umum } \\
\text { secara klasikal dan } \\
\text { diberi skor secara } \\
\text { individu }\end{array}$ \\
\hline $\begin{array}{l}\text { Menyajikan } \\
\text { fabel }\end{array}$ & $\begin{array}{l}\text { Tugas memerankan } \\
\text { fabel }\end{array}$ & $\begin{array}{l}\text { Kesesuaian dengan isi } \\
\text { Karakter tokoh } \\
\text { Intonasi } \\
\text { Volume }\end{array}$ & $\begin{array}{l}\text { Balikan umum } \\
\text { secara klasikal dan } \\
\text { diberi skor secara } \\
\text { kelompok }\end{array}$ \\
\hline Menulis surat & $\begin{array}{l}\text { Tugas menulis email } \\
\text { untuk teman di luar } \\
\text { pulau }\end{array}$ & $\begin{array}{l}\text { Kesesuaian isi surat } \\
\text { Sistematika surat } \\
\text { Penggunaan kalimat } \\
\text { Penggunaan kata } \\
\text { Penggunaan ejaan }\end{array}$ & $\begin{array}{l}\text { Balikan umum } \\
\text { secara klasikal dan } \\
\text { diberi skor secara } \\
\text { individu }\end{array}$ \\
\hline
\end{tabular}

